\title{
Neural Retina
}

National Cancer Institute

\section{Source}

National Cancer Institute. Neural Retina. NCI Thesaurus. Code C33166.

A layer of nerve cells in the retina. Embryologically, it is part of the brain. Incoming light passes through nerve-fibres and intermediary nerve cells of the neural retina, before encountering the light-sensitive rods and cones at the interface between neural retina and the pigmented retinal epithelium. 